\title{
Contents: Film Education Journal 4(1)
}

Decolonizing processes in film education

Jyoti Mistry

Film education in a migration society: A conversation

Alejandro Bachmann, Christine Kopf and Manuel Zahn

and media access in a crisis

Justine Atkinson and Firdoze Bulbulia

Greek teenagers' cultural taste and identity expression through a documentary-making project

Eirini Arnaouti

Cinema en curs: Transmission of film as creation and creation as experience

Núria Aidelman Feldman and Laia Colell Aparicio

Exploring the place of animation and the role of the classroom-based film-maker within a wider field of Scottish moving image education

Robert Munro and Jonathan Charles

This is an open-access journal distributed under the terms of the Creative Commons Attribution Licence (CC-BY) $4.0 \mathrm{https}: / /$ creativecommons.org/licenses/by/4.0/, which permits unrestricted use, distribution and reproduction in any medium, provided the original author and source are credited. https://doi.org/10.14324/FEJ.04.1.00. (ISSN 2515-7086). https://www.uclpress.co.uk/pages/film-education-journal 